\title{
sciendo
}

\author{
RESEARCH PAPERS FACULTY OF MATERIALS \\ SCIENCE AND TECHNOLOGY IN TRNAVA \\ SLOVAK UNIVERSITY OF TECHNOLOGY \\ IN BRATISLAVA
}

2019, Volume 27, Special Number $\quad$ DOI 10.2478/rput-2019-0044

\section{THE ROLE OF SENIORS IN THE INTERGENERATIONAL COOPERAION WITHIN ORGANIZATIONS}

\author{
Monika ŠESTÁKOVÁ ${ }^{1}$ \\ ${ }^{1}$ City UniVERSITY BRATISLAVA \\ ${ }^{1}$ COLLEGE OF MANAGEMENT \\ PANÓNSKA CESTA 17, 85104 BRATISLAVA, SLOVAK REPUbliC \\ e-mail: msestakova@vsm.sk \\ Received 27 September 2019, accepted 25 October 2019, published 6 December 2019
}

\begin{abstract}
The basic objective of the paper is to show that seniors (even in the age 70+) need not be treated just as a burden or as an object of social care and health care (which is, of course, important as well), but that they can be an important production factor in the traditional meaning of the concept in economic theory and can form a valuable component of an intellectual capital in a knowledge-based society. Objective reason of the growing interest in these issues is the aging of population during the last decades (especially in developed countries) and a greater availability of highly skilled seniors, that although meet the requirements to go retired, prefer to work longer and seek in the work (similarly as during their previous active years) a way of selfactualization and a source of vital energy. Keeping employed these seniors can be also economically effective for organizations.
\end{abstract}

\section{Key words}

Intergenerational cooperation at the workplace, role of working seniors, intergenerational knowledge transfer, economic benefits to organization from employing seniors, specific aspects of the intergenerational cooperation at universities

\section{INTRODUCTION}

Intergenerational cooperation is a multidisciplinary research area. Works of sociologists probably prevail, but there are many psychologists, management theoreticians, experts from the knowledge management and also economists dealing with these issues. The shift of attention from the general socio-economic problems of intergenerational cooperation and communication, or from the analysis of intergenerational relations in the family life, to intergenerational context of working communities in organizations and the management of such teams (Browning 2017, Ng and Parry 2016, Baran and Klos 2014, Zemke 2000, Magd 2003) has been a response to some objective trends. The objective background is basically the aging of population in developed countries during the last decades and its relevance also to business 
organizations Acknowledgement of the importance of these issues is visible also from some publications by international organizations (Naegele and Walker, 2006).

Although basic psychological characteristics of different generations may be similar in different countries, the impact of specific socio-political development in a particular country (or group of countries) is important. That's why works of our colleagues from other former transitional economies (e.g. Skibiński 2016, Tokarz et.al. 2012, Baran 2014, Veingerl et. al. 2017) can be inspiring also for us.

Present paper is focused on an older part of recent seniors - age group of 70+. This group is rather scarcely represented in the active workforce and no exact statistics is available. However, in the academic area - at universities and in research institutions - there still actively work some members of this generation. Because of this situation, no wider statistical investigation was possible and questionnaire research would not be representative enough. Instead the conclusions (or hypotheses?) in the paper have been formulated on the basis of author's own experience and interviews with colleagues of the similar age and position. A tentative feedback has been provided by younger colleagues and university students.

The second part of the paper briefly explains what types of generations are represented in the workforce today. The third part tries to show what benefits to the organization can bring the employing of seniors - that are still able (physically and intellectually) and motivated to actively participate. The fourth part focuses on some specific features of the intergenerational cooperation and knowledge transfer at universities. Finally, some tentative recommendations for managing intergenerational teams (where also seniors are included) are formulated.

\section{WHAT GENERATIONS ARE AT WORKPLACE TODAY}

Most authors mention four generations included into the workforce of organizations today: veterans (seniors), baby-boomers, generation X and generation Y. Of course, the share of different generations differs and is changing over time. Basic characteristics of the four currently present generations from the point of view of workplace attitudes, motivation and communication are given in the Table 1 .

Table 1 Differences between Generations

\begin{tabular}{|c|c|c|c|c|}
\hline $\begin{array}{c}\text { Workplace } \\
\text { characteristics }\end{array}$ & Veterans & Baby Boomers & Generation X & Generation Y \\
\hline Work Ethic & $\begin{array}{c}\text { Respect authority, hard } \\
\text { work }\end{array}$ & $\begin{array}{l}\text { Workaholics, desire } \\
\text { quality, question } \\
\text { authority }\end{array}$ & $\begin{array}{l}\text { Eliminate the task, } \\
\text { self-reliant, skeptical }\end{array}$ & $\begin{array}{c}\text { Multitasking, Tenancy, } \\
\text { Entrepreneurial }\end{array}$ \\
\hline Work is... & An obligation & An exciting adventure & A difficult challenge & A means to an end \\
\hline Communication & Formal Memo & In person & Direct, immediate & e-mail, voice mail \\
\hline Motivation & Being respected & $\begin{array}{l}\text { Being valued and } \\
\text { needed }\end{array}$ & $\begin{array}{c}\text { Freedom and removal } \\
\text { of values }\end{array}$ & $\begin{array}{l}\text { Working with other } \\
\text { bright people }\end{array}$ \\
\hline Work/life Balance & Keep them separate & $\begin{array}{l}\text { No balance "Live to } \\
\text { work" }\end{array}$ & Balance "Work to live" & Balance \\
\hline Reward & A job well done & $\begin{array}{l}\text { Money, title, } \\
\text { recognition }\end{array}$ & Freedom & Meaningful work \\
\hline
\end{tabular}

Source: (Zemke et al., 2000)

We are not going into details regarding individual generations, they are sufficiently described in the literature (e.g. Zemke et al. 2000; Argote, 2000; Veingerl et al. 2017, Šafránková, 2019). Just some work-related features will be mentioned that are important for intergenerational cooperation within professional teams (communities). As our paper is focused 
mainly on the seniors generation, our characteristics of individual generations will not fully respect the chronological order (period in which the members of the generation were born).Seniors and baby-boomers co-existed and co-operated in organizations for a long time and formed some "classical standards" of work related values.

The largest and still the most influential generational group are baby-boomers, the generation born mainly in the 1960s or late 1950s. Representatives of this group today still are at the leading positions in organizations. Although there are differences between individuals in each generation, baby-boomers are usually characterized as workholic, respecting authority but also demanding to be respected, often preferring work performance and recognition before personal and family life.

The generation of seniors or veterans includes the people born during the war, or after the war and during early 1950s. Some authors characterize the veterans generation as a „,silent generation"- because they have grown in the time of war and different political disturbances when it was difficult to express own opinion.

From a work-attitude perspective, the generation of seniors has many common features with baby-boomers. Both groups are to a high degree workaholic, they appreciate the "work well done", in the communication at the workplace they prefer personal communication, they like being valued and are happy if they feel they are needed. Both groups are interested in a success of the organization they work for. The cooperation between the two mentioned generational cohorts has been usually very effective - both professionally and also from the human interrelations point of view.

However, political situation has influenced the intergenerational relations in our country significantly. This is especially true regarding the two mentioned generations. Some highly skilled members of the veteran's generation had to leave their posts at the time when their professional carrier could culminate. In a sense, they became "a lost generation". Some of them came back after the velvet revolution and are still among the people that irrespective of their age can be valueable to organizations and society in general.

The X-generation, although born (in our country) in a period of „,normalization“, entered the labor market under rather optimistic conditions, in the situation of euphoria connected with the velvet revolution. They brought new values, attitudes to work into organizations. Their need of creativity, independence, freedom and removal of some traditional values were critically accepted by some older colleagues. Extreme criticism of this generation to everything connected with the past could be regarded also as a barrier to intergenerational knowledge transfer.

In comparison with older generations, the $\mathrm{X}$ generation was not very loyal to its ,parent“ organization, frequently change their employing organization or start a business of their own. However, while aging, the critical attitude to everything old mitigates and representatives of this generation become more inclined to an intergenerational knowledge transfer and cooperation.

Most Xers prefer to focus on their own sphere of influence - family and friends. Many aren't willing to embrace the $24 / 7$ work ethic, and often put work-life balance over income and career advancement.

Millenial $(Y)$ generation has been just started to enter the workforce. This generation has grown with internet and most of its representatives can't even imagine the life without internet. They are technologically superior to older generations. Because of their capability to access information globally, they have a global understanding of the world, different cultures, environmental problems, etc. However, they sometimes lack the experience and previous knowledge to critically evaluate the huge amount of available information.

This generation can be the driver of Industry 4 development -but only in cooperation and knowledge transfer with older generations. 


\section{HOW SENIORS CAN CONTRIBUTE TO ORGANIZATION'S PERFORMANCE}

The basic strength of this generation is its experience and accumulated knowledge (mainly tacit knowledge). Transfer of this knowledge is inevitable for a sustainable development of an organization. When included into the working community, this knowledge transfer can be interactive, not just one directional (Skibiński, 2016, Magd, 2003). A part of the tacit knowledge that seniors can bring to the organization are also their links to suppliers, customers and other representatives of external environment that can be useful also in the future.

Seniors are usually loyal to the organization, many of them have worked for the same organization over the whole life-time. Seniors can be also the representatives of organization memory and they can contribute to the strenghtening of the organization culture.

Seniors tend to focus on processes, rules and protocol and can suggest interesting ideas to improve the processes and integration between organizational functions. However, these suggestions are usually formulated modestly, not in authoritarian or conflict promoting style. Seniors are aware of the fact that today they can't apply for leading positions in organizations and if they suggest some organizational changes, this is not subjectively biased.

Many years of experience in cooperating with different age groups makes from seniors tolerate persons, understanding the different views of cooperating partners and their motivation. This attitude can be important in forming transgenerational and diversified teams and sometimes can be helpful for conflict resolution.

The mentioned features, together with the high work ethics and relatively low payment requirements of seniors and savings that organizations can achieve due to not losing valuable expert knowledge, makes from retaining seniors in the workplace an economic advantage for the organization.

On the other hand, seniors can be more frequently sick or physically disabled which can lead to discontinuities in some processes and activities and problems to an organization. A disadvantage of older employees can be also their slower response flexibility in a reaction to new situations or not understanding enough the potential benefits of new sophisticated IT technology. However, these weaknesses can be to a certain degree solved via collective learning process in intergenerational teams.

\section{INTERGENERATIONAL RERLATIONS AT UNIVERSITIES}

Universities (or academic environment in general) are the area where highly skilled seniors still play an important role. Their knowledge and skills, accumulated over many years of teaching and research, makes from them a component of an intellectual capital that institutions prefer to keep in the active workforce - even if the physical age of these professionals is significantly above the official retirement level.

Although the explicit knowledge is codified in publications, computer programs, prototypes of new products and equipment, etc., and is dramatically increasing at an unprecedented rate, the tacit knowledge, connected with senior professionals, is very important for the teaching process, defining and implementing research programs and also for the human relations in an academic environment.

Co-existence of different generations has been always typical for educational institutions. Students were representing the youngest generation (with some specifities in each period, but also some similarities) and teachers of different age groups were co-operating in the teaching process. Today's seniors have got some experience in cooperating with different generations participating in the educational process and to a certain degree they represent the organizational memory of these institutions.

Although the necessity of knowledge transfer from seniors to younger colleagues is usually acknowledged in multigenerational teams (and often older colleagues are perceived as natural 
authorities), today seniors do not provoke rivalry relations. They know very well that they can't compete for leading positions. Their ambition is just to contribute to an organization's success.

In the communication with the youngest generation (students, PhD students) the seniors are often more patient, tolerate and willing to spend more time to explain to students some deeper and difficult to understand aspects of the problem and a more general framework (both theoretical context and real importance) into which the analysed problems are incorporated. Students usually appreciate this approach.

In the cooperation with middle-age colleagues the basic role of seniors is to be a partner in the discussion on educational and research issues, suggesting some possible approaches, but not manipulating with their partner's opinion.

The intergenerational transfer of knowledge can't be just one-directional, source recepient model of transferring knowledge from seniors to younger colleagues. It should include a feedback and some form of mutual exchange of knowledge within the team (community).

For seniors, the most important knowledge to be acquired through intergenerational cooperation, is the improvement in IT skills, better understanding of recent IT technology and new types of sophisticated software. This higher IT literacy can help them to better understand problems to be solved and become a more valuable partner in the intergenerational cooperation. This is useful not only for seniors subjectively, but also for the whole society in the era or digitalization.

Of course, universities and other organizations as well, can use also other forms of benefiting from the knowledge accumulated by seniors. Instead of including them into active workforce, they can ask them to prepare comments on some important documents or projects of the organization (use them as consultants), they can offer them teaching occasionally some training courses, invite the veterans to some organization's events, etc. Seniors usually welcome these opportunities to renew the contact with their former employer and former colleagues. However, the basic disadvantage of such occasional contacts is the lack of feedback (or very limited feedback) from the organization to the former employees. It is not an exchange of knowledge.

\section{SOME TENTATIVE RECOMMENDATIONS FOR MANAGING INTERGENERATIONAL TEAMS}

Intergenerational teams will probably be used also in the future, especially in the areas, where an intellectual capital is very important for increasing competitiveness of the organization. If we take into account that a large cohort of today's baby-boomers is approaching the age of seniors, making use of knowledge and experience of all the "older" employees becomes inevitable for sustainable development of organizations,

Although it is clear that potential benefits of employing older professionals will differ among organizations, will depend on the supply of highly skilled seniors, area of activity, etc, and with entering the baby-boomers into the group of seniors the average age in multigenerational teams can decline, some tentative recommendations regarding the employment of seniors can be formulated.

- Let seniors work in the professional community as long as they are willing and physically and intellectually able to effectively participate (of course, if it is possible under given legal conditions);

- Create favorable environment for intergenerational cooperation, with better understanding the features of individual generations, but not applying a discriminating approach with regard to some generation. Equal treatment is important; 
- Listen to suggestions from different age groups, do not reject them immediately, think them of. May be, they will be useful in the future;

- If due to existing regulations, it is impossible to directly employ older professionals, use other forms to keep contacts with former employees and let them share - at least to some degree - the topical issues and vision of their former employing organization, This can contribute to the loyalty of existing employees and strengthening the organization culture (and probably also the image of the organization);

- Let the „silent generation“ not to be quite silent and create conditions enabling them to express their opinion regarding the crucial problems of the organization's development.

\section{References}

[1] ARGOTE et al. 2000. Knowledge Transfer in Organizations: Learning from the Experience of Others. Organizational Behavior and Human Decision Processes, 82(1), pp. 1-8.

[2] BARAN, M. and KLOS, M. 2014. Managing an intergenerational workforce as a factor of company competitiveness. Journal of International Studies, N.1, pp. 94-101.

[3] BROWNING, M. 2017. Five Ways to Foster Collaboration in a Multigenerational Workforce. Forbes, 2017/6/22.

[4] NG, E.S. and PARRY, E. 2016. Multigenerational Rersearch in Human Resource Management. Research in Personnel and Human Resources Management, Vol. 34, pp. 1-4.

[5] HEATH, J. 2013. The Structure of Intergenerational Cooperation. Wiley online Library.

[6] MAGD, H. 2003. Management attitudes and perceptions of older workers. International Journal of Contemporary Hospitality Management, 15(7), pp. 393-401.

[7] NAEGELE, G. \& WALKER, A. 2006. A guide to good practice in age management. European Foundation for the Improvement of Living and Working Conditions.

[8] SKIBIŃSKI, A. 2016. An Intergenerational Cooperation in the Organization - View from the Age Perspective. Procedia - Social and Behavioral Sciences. November, pp. 412-419.

[9] ŠAFRÁNKOVÁ, J. M. 2019. Diference v př́stupech k zaměstnání současných generací na trhu práce. (Differences in approaches to employment of existing generations at the labor market.) Paper presented at a conference "Managing Generations". Trnava: MTF STU.

[10] VEINGERL, Ž, ČIČ , S., ŠAROTAR, Ž. 2017. Intergenerational Cooperation at the Workplace from the Management Perspective.

[11] HEATH, J. 2013. The Structure of Intergenerational Cooperation. Wiley online Library.

[12] TOKARZ, B., KAMIŃSKA, Ł., KRZYŻANOWSKA, L. 2012. Dobre praktyki $w$ działaniach międzypokoleniowych na podstawie doświadczeń programu "Seniorzy w akcji" Problémy Polityki Spolecznej. Studia i dyskusje. 17, pp. 167-185.

[13] ZEMKE, R., RAINES, C., FILIPCZAK, B. 2000. Generations at work: Managing the clash of veterans, boomersyour workplace. Researchgate. 